I. Milieva, PhD, Associate Professor M. Khodakivska, Senior Lecturer Kharkov national university of civil engineering and architecture, Kharkiv

\title{
METHODS OF READING TEXTS IN THE FIELD IN UKRAINIAN AS A FOREIGN LANGUAGE
}

The article deals with issues related to communication activities taught by foreign citizens. Attention is drawn to the fact that there are many unresolved issues in the methodological literature concerning the passive types of communicative activity. This article is devoted to one of these types - reading, and more specifically to problems related to different types of reading in classes from Ukrainian as a foreign language. After analyzing some of the issues surrounding the topic of the study, attention is drawn to this type of reading preparation work as a study. It is emphasized that professional texts that are of practical importance for foreign students play an important role in the study of reading, helping to master the future profession. The authors of the article provide a brief description of the types of work with texts and recommendations on the types of tasks to work with them. A set of tasks for working with the text "What is Architecture?" is offered. This text can be used in classes with students of the first year of architectural and construction specialties. The pre-reading tasks are described in detail and specific examples of their application are presented (tasks for eliminating lexical difficulties, tasks for working with keywords of the text, tasks for recognizing words on formal and semantic grounds, on learning grammatical constructions, as well as tasks for improving grammatical skills). Examples of tasks that are performed directly while reading are offered, as well as post-reading tasks that are limited to traditional tasks (complete sentences based on text, retype text, etc.). Attention is also paid to the organization of methodical work in which it is possible to achieve positive results, in the text should be relevant, the texts should be selected according to the speech level of foreign students, the tasks before the text should be aimed at overcoming lexical and grammatical difficulties, and after the text should be set by the purpose is to test reading comprehension and to prepare for reproduction of the text.

Keywords: Ukrainian as a foreign language, types of reading, study reading, professional text, pre-text tasks, post-text tasks, grammatical constructions.

Problem statement. The issues of improving the forms and methods of teaching Ukrainian as a foreign language and adaptation to the new living conditions remain among the pressing challenges of modern education. Each one of the four types of communication activity that are taught to foreign students (speaking, listening, writing, reading) has many unsolved issues.

The relevance of this study is emphasized by the fact that for the foreign students, Ukrainian language is not only an academic subject but also a means of personal development and acquiring expertise, however scientific and methodological literature dedicated to the study of Ukrainian as a foreign language lacks specific guidelines on how to learn reading professional texts, which would optimize the learning process. Learning foreign language in higher education establishments cannot be an end in itself. It should equip the future professional with powerful capabilities for sourcing information that could be used in their professional interests [1]. Therefore, special attention is required for developing skills in close reading of professional texts. The practical significance of this study is that it provides a system of tasks designed to teach close reading of specialized texts to foreign students, which can be used in the practice of teaching Ukrainian as a foreign language.

Purpose and objectives. The purpose of the article is to describe in detail methods for teaching close reading and to demonstrate practical use of the developed methods on a piece of written specialized text and a set of related tasks.

Analysis of recent research and publications. The generalized theoretical aspect of teaching Ukrainian as a foreign language was developed by such prominent education scientists as L. Bey, I. Kochan, D. Mazuryk, T. Lahuta, B. Sokil, O. Trostynska, H. Tokhtar, N. Stankevych. Modern research in the area of learning professional texts in foreign language were to some extent covered in scientific inquiries of K. Kusko, T. Yakhontova, and others. Over the past five years, there have been a number of textbooks presenting texts of different styles and the related methodological apparatus. Scientists note that for the foreign students the ability to read correctly, depending on the communication attitude, and to use different types of reading is a fundamental skill that affects learning outcomes and acquisition of relevant knowledge for the future speciality [2, p. 21].
The Department of Ukrainian Language and Language Training of Foreign Residents of the Kharkiv National University of Construction and Architecture has prepared manuals and a basic textbook for practical training in Ukrainian as a foreign language, which include both texts on Country Studies and professional texts [3]. N. Kravtsova is the author of guidelines intended for independent reading of adapted texts by foreign students. This small edition consists of three sections and includes 19 adapted narratives for reading, pre-text Ukrainian-French minidictionary and post-text questions and tasks [4].

Presentation of the main material. As one of receptive skills concerning perception and comprehension of written text, reading is one of the major types of communicative and cognitive activities. Usually, it starts from reading with the aim to vocalize the language material, train pronunciation, word stress, and develop correct intonation; and then reading has communicative and pragmatic goals, and gradually foreign students start treating it as a way to gain information. It is paramount that a student should be able to utilize all types of reading because only then one can aptly combine them, now constituting "mature" or "mobile" reading, for any purpose: aesthetic, pragmatic, or cultural [5, p. 191].

Reading accomplishes several functions, including assistance in developing other types of communicative activities, such as oral and written productive skills. This is why most teachers of Ukrainian as a foreign language employs different types of reading. As it is commonly known, there are several distinguished types of reading: skimming, scanning, general reading, and close reading. The first two types are supplementary and arise only as an accompanying element in the development of other types of reading [6, p. 273]. Foreign students should first and foremost be taught close reading. Such reading results in "processing" of information, i.e. its organization and critical evaluation. We find it crucial that memorization of language material and formation of a vocabulary takes place precisely during the development of close reading skills.

Close reading involves as full and precise understanding of all the information contained in the text as possible, as well as its critical comprehension. It is distinguished by rereading parts of the text, sometimes with the use of expressive reading of the text to oneself or aloud, 
establishment of the meaning behind the text by analysing linguistic forms, marking the most important points, memorization of the content for subsequent retelling, discussion of the text, and using it in one's work. It is close reading that teaches one "careful attitude" towards the text. It is certain that the purpose of close reading is complete perception and comprehension of the text. This requires thorough preparation, a system of exercises and tasks that monitor the level of comprehension of the text and provide step-by-step transition to oral and written speech. We can propose various types of lexico-grammatical tasks for close reading of specialized texts.

The below text "What is Architecture?" is accompanied by the proposed set of lexico-grammatical exercises. This text is used in the classes of Ukrainian as a Foreign Language with first-year students of the speciality 191, Architecture and City Planning (first content module). The training material for the classes with foreign students is selected based on the level of proficiency in Ukrainian language. This small (105 words) text corresponds with the cognitive interests of the students, it is work-related and has a sufficient amount of specific vocabulary, since future professionals should pay special attention to terminology, as it was fairly pointed out by L. Filiuk [7].

So, let's consider the tasks that can be offered to foreign students during close reading of a professional text. What is Architecture?

An architect is an old profession. Architecture is both a science and an art. It studies the laws of construction of buildings and structures. An architect is a professional who knows the laws of architecture. An architect creates designs of buildings and structures, and manages their construction. An architect designs an artificial habitat. An artificial habitat is all that man has erected for life. Artificial habitats are cities, factories, power plants, buildings, residential buildings, public buildings, parks, and recreation areas. Works of architecture are organic combinations of science, technology and art.

A builder is also an old profession. A builder implements the architect's design. A builder erects buildings, including residential buildings, erects cities, factories, factories, and public buildings. A builder must know the laws of construction and architecture.

A builder and an architect are ancient professions.

Before the text, we offer a set of tasks which not only explain the new material, but also activate the students' experience with the language required for reading of the presented text. The main goal of the pre-text block is to eliminate lexicogrammatical difficulties with the piece of specialized text. To achieve this goal, we use various types of tasks.

Tasks for eliminating lexical difficulties. For example:

Write down new words and phrases. To build - build (what?); to design - design (what?)...

Tasks for working with text keywords. For example:

Read the sentences. Find out what is a building and how it differs from a structure. Write down the definition of the terms "structure" and "building".

A structure is a bridge, a residential building, a palace, a stadium, a monument, a power plant, a factory, an underground station, a swimming pool.

A building is a residential building, a cinema, a school, a university, a library, a hostel, a supermarket.

Task for identification of words by formal and semantic characteristics. For example:

Task 1. Read the following and ask questions to the words. Find and write down the words that contain the same root.

Architectural, construction, design,....
Task 2. Analyse the words by the structure. Explain their meaning.

Residential, construction, designer,....

Tasks for identifying grammatical structures. For example:

Read the sentence. Replace the nominative case of the predicate with the instrumental case (what is what $\rightarrow$ what is [represented] by what).

Architecture is the art of building design. Architecture is [represented] by..., etc.

Tasks for improving grammatical skills. For example:

Task 1. Inflect the verbs in the present and past tense.

For example: to build - I build, you build, he (she) builds, we build, you build, they build; he built, she built, they built.

Design, manage...

Task 2. Put the nouns and phrases in the instrumental case. Form sentences with them.

An old profession, ancient professions...

Task 3. Using the suggested options, tell us who your friends would want to become (choose your own names).

An economist, a historian, a philologist,...

Students perform in-text tasks directly while reading. Such a small text could call for at least one task that would draw the students' attention to the fact that the text is a source of practical information.

Read the text and find what-is-what structures within it. Replace them with what-is-represented-by-what structures.

Post-text tasks play an important role in learning reading and are aimed at checking the understanding of what has just been read by the foreign students for the purpose of improvement of various skills necessary for further interpretation of the text. Post-text tasks to the proposed text comprise traditional tasks: end the sentences using the text, question - answer (performed twice: first, using the text, and second, without it), retell the text (using the notes). For example:

Task 1. Finish the sentences using the text: 1. Architecture is.... 2. Architecture studies.... etc.

Task 2. Answer the questions. 1. What is architecture? 2. What does architecture study? 3...

Task 3. Retell the text, use the notes and answers to previous tasks.

To rate the understanding of the content of the text by foreign students, we offer test tasks, such as:

Task 1. Select a word that best completes a lexical sting:

1. An architect, a builder, an engineer,... a) a friend; b) a student; c) a teacher

2. A residential building, a cinema, a hostel,... a) a university; b) a park; c) a city.

3. ...

Task 2. Complete the sentences:

1. An architect is... a) an old profession; b) a combination of science and art; c) a builder.

2. A builder is... a) a student; b) a combination of technology and art; c) a professional.

3. ...

In addition, the post-text stage should include tasks aimed at analysing the structure of the text, the means of communication, as well as tasks with the transition to oral or written speech. It is for a good reason that speaking and reading are considered to be one combined act of speech in the methodology of teaching Ukrainian as a second language. Therefore, post-text tasks not only rate the level of understanding of the text, but also prepare the reader to reproduce the obtained information [8, p. 310].

Pre-text, in-text and post-text tasks help foreign students to better comprehend and process the content of the proposed material. Undoubtedly, reading professional texts 
may cause many difficulties, but properly organized methodical work helps achieve positive results. Firstly, the text must be relevant (from the core subjects that the foreign student studies in parallel with the course "Ukrainian as a Foreign Language"). Secondly, the texts should be selected according to the level of language proficiency of foreign students, and if necessary, the texts should be adapted. Thirdly, pre-text tasks should be aimed at overcoming lexical and grammatical difficulties, and in-text and post-text tasks should test the understanding of what has just been read and preparation to produce text.

Conclusions. In summary, the outcomes of learning Ukrainian as a foreign language depends largely on proper organization of training in terms of reading specialized texts. In particular, close reading helps to better understand the content of the text, develops contextual guessing, activates skills in overcoming lexico-grammatical difficulties, and forms an interest in mastering a foreign language. The set of tasks we proposed is aimed at better comprehension of specialized texts and formation of general rules, which ideally should be followed in order to successfully master close reading skills.

Discussion. Of course, the study does not exhaust all issues regarding teaching foreign students to read specialized texts in classes of Ukrainian as a Foreign Language. Promising areas for further research include preparation of a set of lexico-grammatical tasks on close reading of specialized texts at advanced level of studying Ukrainian as a foreign language, as well as methodical development of materials for learning skimming when working with foreign students, as these questions are open to dispute due to unclear definition of boundaries between different types of reading and system of tasks for them.

References

1. Tohtar, G.I., 2005. Problemy navchannia inozemnykh hromadian u VNZ Ukrainy ta shliakhy ikh vyrishennia [Problems of education of foreign citizens in Ukrainian universities and ways of solving them]. Suchasni tekhnolohii pidhotovky fakhivtsiv $v$ umovakh podal'shoho rozvytku vyschoi osvity Ukrainy [Modern technologies of training specialists in the conditions of further development of higher education of Ukraine]. Kharkiv, KhNADU, pp.314-316.

2. Zozulia, I.le., 2018. Navchannia chytannia inozemnykh studentiv ukrainomovnykh tekstiv (pochatkovyj etap) [Learning to read foreign students of Ukrainian-language texts (initial stage)]. Zakarpats'ki filolohichni studii [Transcarpathian philological studios], vol. 5, T. 1, pp. 20-25

3. Krech, T.V., Milieva, I.V., Khodakivska, M.O., 2018. Krokuiemo do fakhu: Praktykum z ukrains'koi movy iak inozemnoi: posibnyk dlia studentivinozemtsiv spetsial'nosti 191 "Arkhitektura ta mistobuduvannia" [Step into the specialty: Workshop on Ukrainian as a Foreign Language: A Handbook for Foreign Students of Specialty 191 "Architecture and Urban Planning"]. Kharkiv, KhNUBA, 113 p.

4. Kravtsova, N.I., 2012. Chytaiemo ukrains'koiu. Teksty dlia samostijnoi roboty z ukrains'koi movy dlia inozemnykh studentiv pidhotovchoho viddilennia [We read in Ukrainian. Texts for independent work in Ukrainian for foreign students of preparatory department]. Kryvyj Rih, KTU, $28 p$.

5. Stankevych, N., 2013. Vydy chytannia v kursi ukrains'koi movy iak inozemnoi [Types of reading in the Ukrainian language as a foreign language]. Teoriia i praktyka vykladannia ukrains'koi movy iak inozemnoi [Theory and practice of teaching the Ukrainian language as a foreign language], vol. 8, pp. 186-193.

6. Lebedynskyj, S.Y., 2011. Metodyka prepodavanyia russkoho iazyka kak ynostrannoho [Methods of teaching Russian as a foreign language]. Minsk, 309 p.

7. Filiuk, L.M., 2015. Ukrains'ka dilova mova dlia inozemtsiv: vyvchennia budivel'noi terminolohii [Ukrainian Business Language for Foreigners: A Study of Construction Terminology]. Mova [Language], №3, pp. 154-159.

8. Liapodovskaia, M.E., 2014. Chtenye v praktyke obuchenyia iazyku kak inostrannomu [Reading in the practice of teaching a language as a foreign language]. Filolohyia i kul'tura [Philology and culture]. no. 4, pp. 308-311.

\section{Список використаних джерел}

1. Тохтар Г.І. Проблеми навчання іноземних громадян у ВНЗ України та шляхи їх вирішення / Г.І. Тохтар, А.П. Кулик // Сучасні технології підготовки фахівців в умовах подальшого розвитку вищої освіти України. - Харків: ХНАДУ, 2005. - С. 314-316.

2. Зозуля IЄ. Навчання читання іноземних студентів україномовних текстів (початковий етап) / І.Є. Зозуля // Закарпатські фрілологічні студії. - 2018. - Вип. 5. - T. 1. - С. 20-25.

3. Крокуємо до фаху: Практикум з української мови як іноземної : посібник для студентів-іноземців спеціальності 191 "Архітектура та містобудування" / Т.В. Креч, І.В. Мілєва, М.О. Ходаківська. - Х. : ХНУБА, 2018. $-113 \mathrm{c}$

4. Кравцова Н.І. Читаємо українською. Тексти для самостійної роботи з української мови для іноземних студентів підготовчого відділення / Н.І. Кравцова. - Кривий Ріг: Видав. центр КТУ, 2012. - 28 с.

5. Станкевич Н. Види читання в курсі української мови як іноземної / Теорія і практика викладання української мови як іноземної / Н. Станкевич. - 2013. - Вип. 8. - С.186-193.

6. Лебединский С.И. Методика преподавания русского языка как иностранного : учеб. пособ. / С.И. Лебединский, Л.Ф. Гербик. - Минск, 2011. - $309 \mathrm{c}$

7. Філюк Л.М. Українська ділова мова для іноземців : вивчення будівельної термінології / Л.М. Філюк. - Мова. - 2015. - №3. - С. 154-159.

8. Ляподовская М.Е. Чтение в практике обучения языку как иностранному / М.Е. Ляподовская // Филология и культура. - 2014. - №4 (38). C. $308-311$

Надійшла до редколегії 18.01.20

І. Мілєва, канд. філол. наук, доц

М. Ходаківська, старш. викладач

Харківський національний університет будівництва та архітектури, Харків

\section{МЕТОДИКА ЧИТАННЯ ТЕКСТІВ ЗА ФАХОМ НА ЗАНЯТТЯХ 3 УКРАЇНСЬКОЇ МОВИ ЯК ІНОЗЕМНОÏ}

Розглянуто питання, пов'язані з видами комунікативної діяльності, яких навчають іноземних студентів. Звернено увагу на те, що у методичній літературі існує чимало невирішених питань, що стосуються саме пасивних видів комунікативної діяльності. Статтю присвячено одному з таких видів - читанню, а точніше проблемам, пов'язаним із різними видами читання на заняттях з української як іноземної. Після аналізу деяких проблем, що стосуються теми дослідження, увагу звернено на вивчаюче читання. Підкреслено, що важливу роль під час вивчаючого читання виконують фахові тексти, які мають практичну значущість для студентів-іноземців, допомагають в оволодінні майбутньою професією. Наведено стислу характеристику видів роботи з текстами та рекомендації щодо типів завдань для роботи з ними. Запропоновано комплекс завдань для роботи з текстом "Що таке архітектура?", які можна використати на заняттях зі студентами першого курсу архітектурних і будівельних спеціальностей. Детально описано завдання перед прочитанням тексту та подано конкретні приклади їх застосування (завдання на усунення лексичних труднощів, завдання для роботи з ключовими словами тексту, завдання на впізнавання слів за формальною і семантичною ознакою, на впізнання граматичних конструкцій, а також завдання на вдосконалення граматичних навичок). Запропоновано приклади завдань, які виконують безпосередньо під час читання, та завдання після прочитання тексту, які пропоновано обмежити традиційними завданнями (закінчіть речення з опорою на текст, перекажіть текст тощо). Звернено увагу й на організацію методичної роботи, за якої вдається досягти позитивних результатів, тобто текст має бути актуальним, добирати тексти слід відповідно до мовленнєвого рівня іноземних студентів, завдання перед текстом мають бути спрямовані на подолання лексичних і граматичних труднощів, а після тексту повинні ставити за мету перевірку розуміння прочитаного й підготовку до відтворення тексту.

Ключові слова: украӥнська як іноземна, види читання, вивчаюче читання, фаховий текст, передтекстові завдання, притекстові завдання, післятекстові завдання, граматичні конструкції. 